\title{
REKONTRUKSI HUKUM PERKAWINAN BEDA AGAMA DALAM PERSPEKTIF UNDANG-UNDANG NOMOR 1 TAHUN 1974 TENTANG PERKAWINAN DAN UNDANG-UNDANG NOMOR 24 TAHUN 20013 TENTANG PERUBAHAN ATAS UNDANG-UNDANG NOMOR 23 TAHUN 2006 TENTANG ADMINISTRASI KEPENDUDUKAN
}

\author{
Moh. Zeinudin ${ }^{(1)}$ \\ Arief Santoso ${ }^{(2)}$ \\ ${ }^{(1)}$ Dosen Program Studi Magister Hukum \\ Pascasarjana Universitas Wiraraja \\ ${ }^{(2)}$ Dosen Fakultas Hukum Universitas Wiraraja \\ zain.fh@wiraraja.ac.id ${ }^{(1)}$ \\ arifsantoso@wiraraja.ac.id ${ }^{(2)}$
}

\begin{abstract}
ABSTRAK
Hukum perkawinan beda agama masih terus terjadi, walaupun telah keluar Putusan Mahkamah Konstitusi Nomor 68 Tahun 2014 yang menolak secara keseluruhan permohonan perkawinan beda agama. Perdebatan akademik juga terus terjadi dalam sejarah politik hukum perkawinan di Indonesia. Bahkan jika dikaji dengan seksama, Undang-Undang Nomor 1 Tahun 1974 Tentang Perkawinan (UUP) yang merupakan kodifikasi hukum perkawinan nasional yang berlaku di Indonesia juga tidak mengatur perkawinan campuran beda agama. Kondisi pengaturan hukum yang demikian, telah melahirkan beragam penafsiran hukum dan yurisprudensi tentang hukum perkawinan beda agama, baik yang sifatnya mengabulkan, maupun yang menolak permohonan perkawinan beda agama. Beberapa hasil penelitian menunjukkan bahwa perkawinan beda agama terus terjadi dalam berbagai bentuk praktiknya di Indonesia dengan memanfaatkan celah-celah hukum dan keragaman penafsiran tentang syarat sahnya perkawinan menurut hukum agama sebagaimana diatur dalam pasal 2 ayat (1) UUP. Artikel ini akan mengkaji dinamika pengaturan perkawinan beda agama menurut UUP dan Undang-Undang Nomor 24 Tahun 2013 Tentang Perubahan atas Undang-Undang Nomor 23 Tahun 2006 Tentang Administrasi Kependudukan (UU Aminduk).
\end{abstract}

Kata Kunci : Rekontruksi Hukum, Perkawinan dan Beda Agama 


\section{A. PENDAHULUAN}

Pasal 2 ayat (1) Undang-Undang Nomor 1 Tahun 1974 Tentang Perkawinan menyebutkan, bahwa "perkawinan adalah sah, apabila dilakukan menurut hukum masingmasing agamanya dan kepercayaannya itu”. Berdasarkan pasal ini, dapat dipahami bahwa sebuah perkawinan dianggap sah jika dilaksanakan menurut hukum agama para pihak yang melangsungkan perkawinan. Dengan demikian, apabila suatu perkawinan tidak dilakukan menurut hukum agama para pihak yang melangsungkan perkawinan, maka negarapun tidak akan mengakuinya sebagai perkawinan yang sah.

\section{Menurut Alyasa Abubakar,} negara tidak mempunyai cara pernikahan sendiri di luar aturan agama. Dengan kata lain, negara tidak mengakui pernikahan yang sekuler. ${ }^{1}$ Ketentuan ini relatif bertolak belakang dengan salah satu aturan peninggalan Belanda, yaitu di Gemengde Huwelijken Regeling (selanjutnya akan disebut GHR) yang menyatakan bahwa perbedaan agama, bangsa atau asal usul sama sekali tidak menjadi penghalang untuk melakukan perkawinan (pasal 7 ayat (2) GHR).

\footnotetext{
1 Alyasa Abubakar, 2008, Perkawinan Muslim dengan Non Muslim dalam Peraturan Perundang-Undangan, Jurisprudensi, dan Praktek Masyarakat (Nanggroe Aceh Darussalam: Dinas Syariat Islam, h. 6.
}

ISSN Cetak \& Online : 2355-5831/ 2355-9934

Dalam GHR ini, negara tidak mengaitkan perkawinan dengan hukum agama, sehingga pernikahan tetap dianggap sah jika dilakukan dengan cukup mengikuti aturan negara. Dengan demikian, GHR tersebut tidak menjadikan perbedaan agama sebagai penghalang terjadinya perjanjian perkawinan.

Bagi seorang yang beragama Islam, bunyi pasal 2 ayat (1) UUP ini berarti telah menutup kemungkinan untuk melakukan perkawinan secara "sekuler" dan juga tertutup kemungkinan melakukan perkawinan berbeda agama, karena pernikahan ini dilarang (tidak sah) menurut hukum islam (aturan fiqih).

Bagi yang beragama Islam, aturan hukum yang melarang untuk melangsungkan perkawinan beda agama adalah masalah penting karena dalam peraturan perkawinan peninggalan Belanda (GHR), penduduk Indonesia (waktu itu Hindia Belanda) diizinkan untuk menikah secara "sekuler" dan perbedaan agama bukanlah penghalang perkawinan. Dalam sejarah, umat Islam berusaha mengubah peraturan buatan Belanda ini, karena di dalam Al-Qur'an tercantum larangan bagi seorang muslim dan seorang muslimah untuk menikah dengan orang musyrik. Namun menurut Arsal, al-Qur'an hanya mengizinkan lelaki muslim melangsungkan perkawinan dengan perempuan ahli 


\section{JURNAL JENDELA HUKUM}

$k_{i t a b}{ }^{2}$

Walaupun sudah ada ketegasan dalam UUP bahwa perkawinan harus mengikuti ketentuan hukum agama, dan karena itu pernikahan seorang muslim dengan orang non muslim harus dihindari, namun dalam praktek yang terjadi justru larangan perkawinan dengan non muslim ini sering diabaikan oleh sebagian umat Islam di Indonesia. Banyaknya kaum selebritis yang beragama Islam yang melakukan perkawinan beda agama dari masa ke masa misalnya, cukup memberikan bukti bahwa aturan hukum yang melarang perkawinan beda agama ini cukup sering diabaikan. Cukup kuat penilaian bahwa sebagian petugas masih mengizinkan dan mengakui pernikahan secara "sekuler" tersebut karena perkawinan beda agama tetap saja terjadi dan dicatatkan oleh Petugas Pencatat pada Kantor Catatan Sipil (selanjutnya ditulis KCS) sebagai perkawinan yang sah.

Memang sebagian ahli hukum berusaha mengembangkan pendapat bahwa perkawinan beda agama tidak diatur dalam UUP. Oleh karena itu, berdasarkan aturan peralihan yang menyatakan bahwa peraturan lama masih tetap berlaku sekiranya tidak diatur

${ }^{2}$ Arsal, 1999, Konsep Ahl Al Kitab dalam Al Qur'an (Studi Analisis Perbandingan Pendapat Mufassirin) Banda Aceh: IAIN Ar Raniry Press. h. 27.

ISSN Cetak E Online : 2355-5831/ 2355-9934

dalam undang-undang ini, maka aturan mengenai perkawinan campuran beda agama yang ada dalam GHR yang telah dikutip di atas, semestinya dianggap masih tetap berlaku. ${ }^{3}$ Lebih dari itu pihak Pegawai Pencatat Perkawinan pun terlihat tidak mempunyai satu sikap. Ada KCS yang hanya mau mencatatkan perkawinannya, tetapi ada juga yang di samping mencatat juga mau membantu menyelenggarakan perkawinannya, bahkan ada yang mau menyelenggarakan sendiri perkawinan beda agama serta mencatatkannya (jadi perkawinannya tidak dilakukan menurut [di depan pemuka] agama). Selain itu, ada juga Pegawai Pencatat Perkawinan pada sebagian KCS yang menganggap perkawinan ini tidak sah dan karena itu tidak mau mencatatkannya.

Realitas seperti ini, dimana aturan hukum dalam Undang-undang dirasakan tidak cukup efektif untuk menghalangi terjadinya perkawinan beda agama dan Pegawai Pencatat perkawinan pun khususnya KCS tidak seragam dalam memberikan tafsir, maka perlu ada kajian rekonstruksi hukum sebagai salah satu solusi hukum perkawinan beda agama yang sulit dicegah berdasarkan UUP dan UU Aminduk.

3 R. Soetojo Prawirohamidjojo. 2002. Pluralisme dalam Perundang-Undangan Perkawinan di Indonesia. Surabaya: Airlangga University Press. h. 23 


\section{JURNAL JENDELA HUKUM}

\section{B. PEMBAHASAN.}

Untuk melakukan sebuah rekonstruksi hukum yang akan ditawarkan sebagai solusi terhadap fenomena perkawinan beda agama yang terus terjadi di Indonesia, maka tetap perlu mengkajinya dalam perspektif berdasarkan UUP, Peraturan Pemerintah Nomor 9 Tahun 1975 Tentang Pelaksanaan Undang-Undang Nomor 1 Tahun 1974 Tentang Perkawinan (PP UUP) dan Undang-Undang Nomor 23 Tahun 2006 Tentang Administrasi Kependudukan (UU Aminduk), sebagaimana telah diubah oleh UndangUndang Nomor 24 Tahun 2013 Tentang Perubahan Atas Undang-Undang Nomor 23 Tahun 2006 Tentang Administrasi Kependudukan sebagai hukum positif di Indonesia.

Dalam Pasal 2 ayat (2) UUP dinyatakan, bahwa: "Tiap-tiap perkawinan dicatat menurut peraturan perundang-undangan”. Pasal 2 ayat (2) UUP ini dengan jelas menegaskan, bahwa "tiap-tiap perkawinan" dapat dicatatkan untuk mendapatkan kepastian hukum berdasarkan peraturanperundangan yang berlaku. Pada poin ini, Penulis berpendapat bahwa pilihan diksi "tiap-tiap perkawinan" ini menunjuk kepada perkawinan yang bersifat umum, baik perkawinan yang dilangsungkan menurut agama Islam yang melarang
ISSN Cetak \& Online : 2355-5831/2355-9934

perkawinan beda agama, maupun perkawinan yang dilangsungkan menurut agamanya dan kepercayaannya menurut selain agama Islam. Dengan menafsirkan yang demikian, penulis juga berpendapat bahwa secara implisit (tersirat), sebenarnya perkawinan beda agama diakui keberadaannya dalam UUP dan dapat dikategorikan sebagai perkawinan yang dilangsungkan menurut agamanya dan kepercayaannya itu menurut selain agama Islam, sebagimana diatur dalam Pasal 2 ayat (2) PP UUP sebagai aturan hukum pelaksana UUP yang berbunyi: "Pencatatan Perkawinan dari mereka yang melangsung perkawinannya menurut agamanya dan kepercayaannya itu selain agama Islam, dilakukan oleh Pegawai Pencatat Perkawinan pada Kantor Catatan Sipil sebagaimana dimaksud dalam berbagai perundangundangan mengenai pencatatan perkawinan".

Pengakuan secara implisit dalam UUP dan PP UUP tentang keberadaan perkawinan beda agama sebagai bagian dari kategori perkawinan yang dilangsungkan menurut selain agama Islam dan dapat dicatatkan guna mendapat kepastian hukumnya ternyata juga diatur dapam UU Aminduk. Pasal 35 poin a UU Adminduk ternyata mempertegas kewenangan bagi Kantor Catatan Sipil untuk melangsungkan 


\section{JURNAL JENDELA HUKUM}

ISSN Cetak \& Online : 2355-5831/2355-9934

perkawinan beda agama. Dalam pasal tersebut disebutkan, bahwa pencatatan perkawinan di Indonesia yang diatur pada Pasal 34 juga berlaku untuk perkawinan yang ditetapkan oleh Pengadilan. Penjelasan Pasal 35 poin a UU Adminduk juga menegaskan, bahwa yang dimaksud dengan "Perkawinan yang ditetapkan oleh Pengadilan" adalah "perkawinan yang dilakukan antar-umat yang berbeda agama yang telah memperoleh penetapan dari Pengadilan". Dengan adanya pengaturan hukum yang jelas dan tegas inilah, penulis berpendapat, bahwa hukum perkawinan beda agama masih bisa direkonstruksi hukumnya dan dapat diberikan kepastian hukum, sebagaimana telah ditegaskan pula di atas bahwa teori keadilan bermartabat meniscayakan adanya penemuan hukum untuk memberikan kepastian hukum terhadap kasus-kasus konkrit yang tidak atau belum diatur secara jelas dan tegas dalam hukum positif.

Jika dikaji secara sepintas, sepertinya terdapat pertentangan norma hukum tentang pelaksanaan perkawinan beda agama sebagimana diatur dalam Undang-Undang Nomor 1 Tahun 1974 Tentang Perkawinan (UUP) dengan UU Adminduk sebagai hukum positif. Di satu sisi, perkawinan beda agama berdasarkan UUP tidak diatur secara jelas dan tegas dan ditafsirkan dilarang dan dianggap tidak sah seperti telah diuraikan di atas, namun di sisi lain pelaksanaannya diberikan jalan keluar dalam UU Adminduk. Oleh karena itu, pertentangan norma hukum tentang pelaksanaan perkawinan beda agama dalam dua Undang-Undang tersebut akan dikaji dengan menggunakan kaidahkaidah dalam teori keadilan bermartabat.

Perkawinan beda agama pada prinsipnya memang tidak disebutkan dalam UUP. Secara materiil, perkawinan beda agama dianggap tidak memenuhi aspek-aspek perkawinan yang dicitacitakan oleh UUP, terutama tentang sahnya perkawinan yang menurut tafsir hukum dominan dinyatakan bahwa prinsip perkawinan di Indonesia lebih mengutamakan perkawinan seagama, dan melarang perkawinan beda agama. Oleh karena itu, perkawinan beda agama dianggap tidak sesuai dengan UUP dan tidak dapat dilaksanakan. Pengaturan pelaksanaan perkawinan beda agama justru muncul dari UU Adminduk yang pada dasarnya mengatur tentang pencatatan sipil kependudukan. Permasalahan pengaturan pelaksanaan perkawinan beda agama dalam UU Adminduk ini dapat menimbulkan diskursus baru tentang hukum perkawinan beda agama yang berdasarkan uraian sebelumnya telah 


\section{JURNAL JENDELA HUKUM}

disimpulkan bahwa UUP, KHI, Fatwa MUI, dan Putusan MK telah melarang perkawinan beda agama, karena dianggap bertentangan dengan hukum agama dan asas Ketuhanan Yang Maha Esa.

Keberadaan Pasal 35 poin a UU Adminduk yang secara jelas dan tegas mengatur dapat dicatatkannya perkawinan beda agama tentu menimbulkan pertentangan norma hukum antara apa yang diatur dalam UUP dan UU Adminduk dalam persolan pelaksanaan perkawinan beda agama. Untuk menyelesaikan pertentangan norma hukum yang mengatur tentang pelaksanaan perkawinan beda agama dalam UUP dan UU Aminduk ini, teori keadilan bermartabat yang memiliki tata kerja yang sistematik dapat digunakan. Sebab menurut teori keadilan bermartabat, tata kerja hukum itu harus berjalan sistematik, tidak boleh ada pertentangan, bahkan berbagai sistem hukum dapat dikompromikan dan diadaptasikan berdasarkan nilai-nilai hukum dan moral sebagai volkgeist Indonesia.

Oleh karena itu, menurut hemat penulis, pengaturan pelaksanaan perkawinan beda agama dalam UUP dan UU Aminduk harus dikompromikan dan ditemukan jalan tengahnya dengan melihat dari hubungan umum dan khusus

ISSN Cetak E Online : 2355-5831/ 2355-9934

antara sahnya perkawinan dan pecatatanya menurut UUP dan UU Aminduk. Pendapat penulis di atas, juga sejalan dengan asas lex specialis derogat legi generalis, yang menjelaskan bahwa aturan hukum yang bersifat khusus dapat menyimpangi aturan hukum yang bersifat umum. Asas ini pada umumnya berlaku untuk undang-undang khusus terhadap undang-undang pokoknya, seperti contoh perbandingan misalanya; Undang-Undang Nomor 4 Tahun 1992 Tentang Perumahan dan Permukiman (UUPP) terhadap Undang-Undang Nomor 5 Tahun 1960 tentang Pokok Agraria (UUPA). UUPA merupakan undang-undang yang hanya mengatur hal-hal pokok dalam bidang keagrariaan, sedangkan UUPP merupakan turunan dari UUPA yang telah mengatur hal-hal khusus yang pada prinsipnya merupakan bagian dari agraria itu sendiri, sehingga dalam hubungan antara UUPP terhadap UUPA dapat berlaku asas lex specialis derogat legi generalis.

Namun hal ini berbeda dengan hubungan antara UUP dan UU Adminduk, karena tidak seluruh substansi undang-undang yang satu merupakan bagian dari undang-undang yang lain. UUP mengatur tentang perkawinan dan memiliki substansi tentang dasar perkawinan, syarat-syarat perkawinan, pencegahan perkawinan, 


\section{JURNAL JENDELA HUKUM}

ISSN Cetak \& Online : 2355-5831/2355-9934

batalnya perkawinan, dl. Sedangkan UU Adminduk mengatur tentang pencatatan peristiwa penting yang terbagi atas kelahiran, kematian, lahir mati, perkawinan, perceraian, pengakuan anak, pengesahan anak, pengangkatan anak, perubahan nama dan perubahan status kewarganegaraan.

Pencatatan perkawinan merupakan salah satu bagian yang diatur dalam UUP yakni dalam Pasal 2 ayat (2), demikian juga dalam UU Adminduk, perkawinan merupakan salah satu jenis peristiwa penting dari berbagai jenis peristiwa penting yang harus dicatatkan agar memiliki kepastian hukum. Oleh karena itu dalam menentukan kedudukan umum-khususnya tidak dapat dilakukan hanya dengan melihat judul undangundangnya saja, tetapi harus dilihat dari segi substansi yang akan dikaji.

Jika dikaji dari segi pencatatannya, maka pencatatan perkawinan secara umum diatur dalam UU Adminduk dan secara khusus diatur oleh UUP. Dari segi pencatatannya, UU Adminduk menetapkan jenis peristiwa penting apa saja yang dapat dicatatkan dan perkawinan merupakan salah satunya. Oleh karena perkawinan merupakan salah satu peristiwa penting yang ditetapkan untuk dicatat, maka kemunculan UUP menjadi aturan yang menetapkan perkawinan yang bagaimana yang dapat dicatatkan. Namun jika dikaji dari segi perkawinannya, maka sahnya perkawinan secara umum diatur dalam UUP dan secara khusus diatur oleh UU Adminduk. Dari segi sahnya perkawinan pada umumnya telah ditetapkan dalam Pasal 2 ayat (1) UUP, yaitu perkawinan dianggap sah apabila dilaksanakan menurut hukum agama yang dianut.

Menurut penulis, munculnya Pasal 35 poin a UU Adminduk memberikan pengecualian untuk pelaksanaan perkawinan beda agama, yaitu harus dengan penetapan Pengadilan. Oleh karena itu, sahnya perkawinan berdasarkan UU Adminduk hanya berlaku pada perkawinan beda agama, dengan demikian UU Adminduk bersifat lebih khusus. Berdasarkan penjelasan tersebut maka UUP berkedudukan sebagai peraturan yang bersifat umum, sedangkan UU Adminduk berkedudukan sebagai peraturan yang bersifat khusus yang dapat menyimpangi aturan hukum yang bersifat umum.

Pasal 35 poin a UU Adminduk pada dasarnya tidak menyebutkan sah tidaknya perkawinan beda agama secara eksplisit, namun pasal tersebut hanya mengatur bahwa perkawinan beda agama yang telah memperoleh penetapan Pengadilan dapat dicatatkan di lembaga pencatatan sipil dengan ketentuan seperti 
ISSN Cetak \& Online : 2355-5831/ 2355-9934

perkawinan di Indonesia pada umumnya sesuai Pasal 34 UU Adminduk. Secara implisit dapat dimaknai dua pengertian. Pertama, bahwa perkawinan beda agama telah dianggap sah setelah memperoleh penetapan Pengadilan. Pengertian ini memberi implikasi bahwa terdapat bentuk pengesahan perkawinan lain selain apa yang ditetapkan pada Pasal 2 UUP, yaitu pengesahan perkawinan menurut Pengadilan. Dari implikasi tersebut dapat pula ditarik makna, yaitu penetapan Pengadilan telah dianggap sama dengan penetapan berdasarkan hukum agama. Kedua, pengertiannya bersifat lebih sempit, yaitu sekedar menunjukkan bahwa Pasal 35 poin a UU Adminduk menempatkan perkawinan beda agama sebatas "dapat dicatatkan". Sedangkan sahnya perkawinan tidak ditetapkan/diatur secara jelas, dan bisa dikembalikan kepada ketentuan hukum sahnya perkawinan menurut UUP.

Sebagai contoh konkrit, penulis sajikan contoh Penetapan Perkawinan Beda Agama di Pengadilan Negeri Surakarta

Nomor:

156/Pdt.P/2010/PN.Ska. mendasarkan putusannya pada Pasal 21 ayat (3) UUP yang memberikan kesempatan kepada para pihak yang pelaksanaan perkawinannya ditolak oleh pejabat pencatatan perkawinan untuk meminta pembatalan penolakan dengan mengajukan permohonan ke Pengadilan. Isi penetapannya ternyata sebagai berikut:

1. Mengabulkan permohonan Para Pemohon

2. Memberikan ijin kepada Para Pemohon untuk melangsungkan perkawinan beda agama di hadapan Pejabat Kantor Dinas Kependudukan dan Pencatatan Sipil Kota Surakarta.

3. Memerintahkan kepada Pejabat Dinas Kependudukan dan Pencatatan Sipil Kota Surakarta untuk melakukan pencatatan tentang perkawinan beda agama Para Pemohon tersebut kedalam Register Pencatatan Perkawinan yang digunakan untuk itu dan segera menerbitkan Akta Perkawinan tersebut.

4. Membebankan biaya permohonan kepada Para Pemohon sebesar Rp 116.000 (seratur enam belas ribu rupiah).

Dalam contoh kasus ini, penulis masih menemukan hal yang dapat menimbulkan ketidakpastian dalam penetapan hakim tersebut, terkait proses perkawinan dan sahnya perkawinan itu sendiri. Berdasarkan penetapan tersebut perkawinan dilaksanakan dihadapan Pejabat Dinas Dukcapil, sehingga terlihat seolah Dinas Dukcapil yang mengawinkan. Di sisi lain berdasarkan 


\section{JURNAL JENDELA HUKUM}

wawancara penulis dengan pihak Dinas Dukcapil, ternyata Dinas Dukcapil sebenarnya hanya melakukan pencatatan perkawinannya saja, sejalan dengan poin ketiga penetapan pengadilan di atas. Dinas Dukcapil sendiri memiliki anggapan bahwa perkawinan beda agama telah ada sejak penetapan Pengadilan tersebut ada, sehingga yang dilakukan Dinas Dukcapil hanya tinggal melaksanakan pencatatan perkawinannya saja. Terkait hal ini, dapat dilihat bahwa di Dinas Dukcapil terdapat tiga perkawinan yang dicatat berdasarkan prosesi perkawinan yang dilaksanakan, yaitu: $^{4}$

1. Perkawinan Islam dilakukan dengan ijab qabul oleh Penghulu di hadapan dan dicatat oleh pejabat KUA, yang kemudian dalam beberapa periode dilaporkan ke Dinas Dukcapil.

2. Perkawinan Kristen, Katholik, Hindu, Budha, Kong $\mathrm{Hu} \mathrm{Cu}$, dan penghayat aliran kepercayaan dilaksanakan di tempat peribadatan atau dihadapan pemuka agama yang akan mengeluarkan suatu bukti perkawinan. Bukti perkawinan tersebut yang menjadi dasar Dinas Dukcapil mencatatkan perkawinan yang telah dilaksanakan.

4 Hasil wawancara dengan Dinas Kependudukan Dan Cacatan Sipil
ISSN Cetak \& Online : 2355-5831/ 2355-9934

3. Perkawinan beda agama yang dianggap ada dengan ditetapkannya dalam Penetapan Pengadilan. Salinan Penetapan Pengadilan tersebut menjadi dasar bagi Dinas Dukcapil untuk mencatatkan perkawinan beda agama.

Berdasarkan uraian di atas, penulis berpendapat, bahwa perkawinan beda agama tetap tidak sah, karena Penetapan Pengadilan tersebut sendiri juga tidak menyebutkan bahwa perkawinan beda agama yang dilakukan menjadi sah. Oleh karena itu sah tidaknya perkawinan tetap didasarkan pada ketentuan dalam UUP. Sedangkan munculnya pasal 35 poin a UU Adminduk hanya memberi jalan khusus untuk melaksanakan dan mencatatkan perkawinan tersebut yaitu melalui Penetapan Pengadilan, yang diketahui bahwa Pengadilan merupakan salah satu tempat lahirnya hukum. Melalui hukum yang dilahirkan oleh pengadilan, Pejabat Pencatat Perkawinan memiliki dasar hukum untuk mencatatkan perkawinan beda agama tersebut. Pengaturan yang demikian menunjukkan konsep pencatatan perkawinan beda agama yang administratif. Pencatatan perkawinan beda agama tidak didasarkan atas sahnya perkawinan tersebut berdasarkan UUP yaitu sah sesuai sahnya menurut hukum agama, namun perkawinan beda agama 


\section{JURNAL JENDELA HUKUM}

ISSN Cetak \& Online : 2355-5831/2355-9934

dicatat karena adanya aturan hukum yaitu Penetapan Pengadilan yang menyuruh untuk dicatatkan.

Berdasarkan penjelasan di atas, memang terlihat Pegawai Pencatat Perkawinan seolah mencatatkan perkawinan yang tidak sah. Berdasarkan Pasal 34 UU Adminduk dicatatkannya perkawinan yang dianggap tidak sah bukan tidak mungkin dilakukan. Pasal 34 ayat (1) UU Adminduk mengatur bahwa perkawinan wajib dilaporkan, serta Pasal 34 ayat (2) UU Adminduk menetapkan berdasarkan laporan tersebut pejabat pencatat sipil mencatatkan perkawinannya. Oleh karena Pasal 34 ayat (1) UU Adminduk tidak menyatakan bahwa hanya perkawinan yang sah saja yang dapat dilaporkan serta Pasal 34 ayat (2) UU Adminduk juga tidak mengatur bahwa hanya laporan atas perkawinan sah saja yang dapat dicatatkan. Menerima laporan atas perkawinan yang sah dan mencatatkannya, sebenarnya hanyalah konsep kebiasaan yang dibangun oleh Dinas Dukcapil, sehingga adanya Penetapan Pengadilan atas perkawinan beda agama memaksa Pejabat Pencatat Sipil untuk keluar dari kebiasaannya menerima dan mencatat laporan perkawinan yang sah dan mencatatkan perkawinan beda agama yang masih belum jelas keabsahannya. Oleh karena itu pencatatan perkawinan
beda agama berdasarkan Penetapan Pengadilan hanya berkonsep administrasi.

Dari uraian sederhana tentang rekonstruksi hukum perkawinan beda agama dalam aspek norma hukum dan pencatatannya di atas, penulis dapat menyimpulkan bahwa, rekonstruksi hukum perkawinan beda agama dalam aspek norma hukum dan pencatatannya, meniscayakan sebuah rekonstruksi hukum yang mengharmoniskan antara substansi sahnya perkawinan menurut hukum agama berdasarkan UUP dan substansi pencatatan perkawinan beda agama berdasarkan UU Aminduk serta PP UUP. Sahnya perkawinan tetap dapat dikukuhkan berdasarkan hukum agama sebagi volkgeist Indonesia, namun terhadap peristiwa penting tentang pelaksanaan perkawinan beda agama diberikan solusi secara administratif dicatatkan ke Kantor Catatan Sipil guna mendapatkan kepastian hukumnya berdasarkan Penetapan Pengadilan.

\section{DAFTAR BACAAN}

\section{Buku}

Alyasa Abubakar, 2008, Perkawinan Muslim dengan Non Muslim dalam Peraturan Perundang-Undangan, Jurisprudensi, dan Praktek 


\section{IURNAL JENDELA HUKUM}

ISSN Cetak \& Online : 2355-5831/ 2355-9934

Masyarakat (Nanggroe Aceh Darussalam: Dinas Syariat Islam.

Arsal, 1999, Konsep Ahl Al Kitab dalam Al Qur'an (Studi Analisis Perbandingan Pendapat Mufassirin) Banda Aceh: IAIN Ar Raniry Press.

Nugraha, M. A, 2013, Dualisme Pandangan Hukum Perkawinan Beda Agama antara Undangundang Nomor 1 Tahun 1974 Tentang Perkawinan dengan Undang-undang Nomor 23 Tahun 2006 Tentang Administrasi Kependudukan. Privat Law.

R. Soetojo Prawirohamidjojo. (2002). Pluralisme dalam PerundangUndangan Perkawinan di Indonesia. Surabaya: Airlangga University Press.

Wahyuni, S. (2016). Kontroversi Perkawinan Beda Agama di Indonesia. Jurnal Hukum Islam.

Wahyuni, S. (2017). Nikah Beda Agama: Kenapa ke Luar Negeri?. Pustaka Alvabet.

Hanifah, M. (2019). Perkawinan Beda Agama Ditinjau dari Undangundang Nomor 1 Tahun 1974 Tentang Perkawinan. Soumatera Law Review.

Rosidah, Z. N. (2013). Sinkronisasi Peraturan Perundang-undangan Mengenai Perkawinan Beda Agama. Al-Ahkam.

\section{Peraturan Perundang-Undangan}

Undang-Undang Nomor 1 Tahun 1974 Tentang Perkawinan

Undang-Undang Nomor 24 Tahun 20013 Tentang Perubahan Atas UndangUndang Nomor 23 Tahun 2006 Tentang Administrasi Kependudukan

Peraturan Pemerintah Nomor 9 Tahun 1975 Tentang Pelaksanaan Undang-Undang Nomor 1 Tahun 1974 Tentang Perkawinan (PP UUP)

\section{Putusan pengadilan}

Penetapan Perkawinan Beda Agama di Pengadilan Negeri Surakarta Nomor: 156/Pdt.P/2010/PN.Ska. 